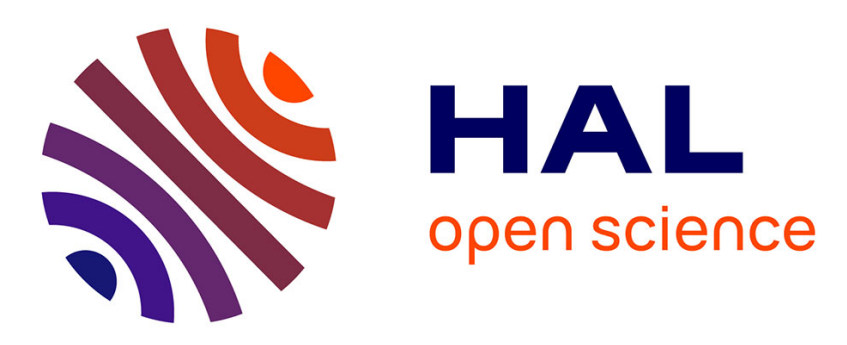

\title{
Measurement of Endurance of Untrained Five-Year-Old and Six-Year-Old Horses Raised in Multi-age Herds on Pasture
}

Anna Brand, Arno Lindner, Hartmut Gerhards, Mathilde Valenchon, Odile Petit

\section{To cite this version:}

Anna Brand, Arno Lindner, Hartmut Gerhards, Mathilde Valenchon, Odile Petit. Measurement of Endurance of Untrained Five-Year-Old and Six-Year-Old Horses Raised in Multi-age Herds on Pasture. Journal of Equine Veterinary Science, 2021, 96, pp.103317. 10.1016/j.jevs.2020.103317 . hal-03021249

\section{HAL Id: hal-03021249 \\ https://hal.science/hal-03021249}

Submitted on 25 Nov 2020

HAL is a multi-disciplinary open access archive for the deposit and dissemination of scientific research documents, whether they are published or not. The documents may come from teaching and research institutions in France or abroad, or from public or private research centers.
L'archive ouverte pluridisciplinaire HAL, est destinée au dépôt et à la diffusion de documents scientifiques de niveau recherche, publiés ou non, émanant des établissements d'enseignement et de recherche français ou étrangers, des laboratoires publics ou privés.

\section{(ㅇ)(1) $\$$}

Distributed under a Creative Commons Attribution - NonCommercial - NoDerivatives| 4.0 
Development of endurance of untrained five- and six-year-old horses raised in multi-age herds

Brand $\mathrm{A}^{\mathrm{a}}$, Lindner $\mathrm{A}^{\mathrm{a}}$, Gerhards $\mathrm{H}^{\mathrm{b}}$, Valenchon $\mathrm{M}^{\mathrm{c}}$, Petit $\mathrm{O}^{\mathrm{c}}$

${ }^{a}$ Arbeitsgruppe Pferd, Juelich, Germany

${ }^{\mathrm{b}}$ Faculty of Veterinary Medicine, Ludwig-Maximilian-Universität Munich, Germany

${ }^{\mathrm{c}}$ Department for Ecology, Physiology and Ethology, IPHC - UMR 7178, CNRS-UDS, Strasbourg, France

Corresponding author: Lindner A, arnolindner@t-online.de; Arbeitsgruppe Pferd, HeinrichRoettgen-Str. 20, 52428 Juelich, Germany

\begin{abstract}
The objective of this study was to examine the endurance of five- and six-year-old horses raised and kept close to natural living conditions and ridden for the first time well into their fifth year of age. Horses were submitted to a standardized exercise test (SET) to calculate their $\mathrm{V}_{4}$ (velocity run under defined conditions inducing $4 \mathrm{mmol} / \mathrm{L}$ of blood lactate concentration (LA)) and $\mathrm{v}_{180}$ (velocity run under defined conditions inducing a heart rate of 180 beats $/ \mathrm{min}$ ). The test consisted of up to five consecutive intervals at increasing speed until the blood LA of a horse increased above $4 \mathrm{mmol} / \mathrm{L}$. The blood LA measured after each interval was plotted exponentially against running speed to derive $\mathrm{V}_{4}$ from the blood lactaterunning speed relationship, and the mean heart rate during the intervals was plotted linearly against running speed to derive $\mathrm{v}_{180}$ from the heart rate-running speed relationship. The following were examined: 1) the development of the endurance variables of five-year-old horses during one year through measurements in September and in the following July and September; the comparison of endurance variables 2) between five- and six-year-olds; 3 ) between six-year-olds on consecutive years; and 4) between six-year-olds and foreign horses. The results showed that: 1$)$ there were no changes of either variable during one year $(\mathrm{P}>$ $0.05)$; 2) there were no significant differences between five- and six-year-olds $(\mathrm{P}>0.05) ; 3)$ no significant differences between six-year-old groups $(\mathrm{P}>005)$; and 4$)$ foreign horses had higher $\mathrm{v}_{4}$ and $\mathrm{v}_{180}$ values than six-year-olds $(\mathrm{P}=0.0001$ and $\mathrm{P}=0.003$, respectively). There was no significant relationship between $\mathrm{v}_{4}$ and $\mathrm{v}_{180}\left(\mathrm{n}=42 ; \mathrm{P}>0.05 ; \mathrm{r}^{2}=0.02\right)$. In conclusion, one additional year on pasture in multi-age herds did not increase endurance variables of five-year-old horses. Thus, the endurance appeared to be consolidated in these horses at the age of five years and additional training seems to be necessary to increase it.
\end{abstract}

Keywords: Behavior; Growth; Husbandry; Pasture; Management

\title{
1. Introduction
}

In Europe, horses are kept mainly for leisure and sports. Their welfare has become of paramount importance for society. Horses in freedom graze for a large proportion of the day, move for up to $10 \%$ of their daily time budget, mostly at a slow walk, and can constantly interact socially [1-3]. However, the traditional management of horses kept in Europe is very different. Most horses are kept individually and indoors with at least reduced social contacts. Further, they are denied the chance to move freely during the whole day and are fed a lot of concentrates [1,2,4-8]. Restricted space availability, costs, tradition, and the belief that horses kept in groups outdoors are more prone for injuries appear to be important reasons for this type of management [7-9]. This despite many studies demonstrating the benefits of keeping horses outdoors and in groups. Under such conditions, horses are healthier and have less behavioral disorders [6,10-14], are easier to handle, need less time to learn riding tasks, and 
bite their trainers less frequently than stall housed horses [14-16]. Connysson et al. [9] observed that a free-range housing system hastened recovery in Standardbred trotters, had positive effects on their appetite, and on recovery of energy balance. Finally, it has been reported that there is no greater risk of injuries than for horses kept in boxes $[13,17]$.

This study is part of a project aiming to understand the influence of an enriched natural environment on the development of four- to six-year-old horses bred for leisure and sports, raised and kept close to natural living conditions: in large social groups, year-round outdoor life (pastures, large stabling), and fed on low-energy food only (i.e. grass, fodder; no concentrates). These horses are broken-in and ridden for the first time when they are well into their fifth year of age; thus, when growth in horses is close to coming to an end $[18,19]$. The purpose of this part of the study was to examine the effect of this management system on the endurance of the horses. For this purpose, they needed to be ridden and this is why they were first tested first late, when they were five-years-old, after receiving minimal schooling to be able to understand the leads of riders.

Two variables were determined to objectively assess the endurance of the horses: $\mathrm{v}_{4}$ and $\mathrm{v}_{180}\left(\mathrm{v}_{4}=\right.$ velocity run under defined conditions inducing a blood lactate concentration of $4 \mathrm{mmol} / \mathrm{L} ; \mathrm{v}_{180}=$ velocity run under defined conditions inducing 180 beats $\left./ \mathrm{min}\right)$. Both variables are widely used to diagnose the level of performance of horses and the effects of conditioning [20-28].

We hypothesized that the endurance of the five-year-old horses would: 1) change over the course of one year moving freely with the herd; 2) be different from that of six-year-olds raised under the same conditions; 3 ) be lower than that of horses in training for sports.

\section{Material and Methods}

\section{$2.1 \quad$ Horses}

The horses involved in this study were continuously monitored by equine veterinarians and the owner consented to all procedures and disclosure of the findings. The stud was established more than 20 years ago. All horses were French Saddlebreds (Selle Française) and bred for pleasure riding and show jumping. All horses were born at the stud and raised in multi-age groups of 20 to 60 horses until sold. All groups lived in large outdoor pastures. During winter, they were still housed in groups in the large outdoor pastures or in smaller pastures with a large collective stable. They were fed with grass plus eventually a complement of forage all year long when needed. Water was provided ad libitum. All horses were vaccinated, dewormed, and had their feet trimmed regularly. Their teeth were checked at least once per year. Horses were broken-in in late summer to early autumn when five-years-old.

For the project, the $\mathrm{v}_{4}$ and $\mathrm{v}_{180}$ values of 17 five- and 24 six-year-old horses were determined (Table 1). Eleven of the six-year-old horses were also tested when they were fiveyears-old. 
Table 1

Five- and six-year-old horses included in the studies on the development and comparisons of $\mathrm{v}_{4}$ and $\mathrm{v}_{180}$ (Total number (Mares/Geldings))

\begin{tabular}{ccccc}
\hline Study & Variable & 5 -year-olds & 6 -year-olds & Foreign horses \\
\hline Development & $\mathrm{v}_{4}$ & $11(8 / 3)$ & - & - \\
for one year & $\mathrm{v}_{180}$ & $7(7 / 0)$ & - & - \\
\hline Comparison between 5- & $\mathrm{v}_{4}$ & $16(10 / 6)$ & $18(7 / 11)$ & - \\
and 6-year-olds & $\mathrm{v}_{180}$ & $16(10 / 6)$ & $12(6 / 6)$ & - \\
\hline Comparison between 6-year- & $\mathrm{v}_{4}$ & - & $201610(3 / 7)$ & - \\
olds & & & $20178(4 / 4)$ & - \\
& $\mathrm{v}_{180}$ & - & $20167(2 / 5)$ & - \\
& & & $20175(4 / 1)$ & \\
\hline Comparison between 6-year- & $\mathrm{v}_{4}$ & - & $22(11 / 11)$ & $13(4 / 9)$ \\
olds and foreign horses & $\mathrm{v}_{180}$ & - & $16(10 / 6)$ & $9(1 / 8)$ \\
\hline
\end{tabular}

$\mathrm{v}_{4}=$ Velocity run under defined conditions inducing a blood lactate concentration of 4 $\mathrm{mmol} / \mathrm{L}$

$\mathrm{V}_{180}=$ Velocity run under defined conditions inducing 180 beats $/ \mathrm{min}$

The number of $\mathrm{v}_{180}$ values was lower than $\mathrm{v}_{4}$ because of missing data during the exercise tests

The five-year-olds were ridden for the first time in mid-July, seven weeks before the endurance test. For this purpose, they were schooled to be ridden straight and on loops at walk, trot, and canter (Figure 1). The intention of the schooling activities was to teach the horses to understand the leads of a rider, not to improve their endurance or any other physical capacity. There was no strict schooling regime. The type and number of activities done per week was fully dependent on the reaction of the horses. Each type of activity had a duration of approximately five minutes, but the exercise outdoors at walk and trot lasted about 20 minutes in total and was introduced in the fourth schooling week. Horses were walked and trotted without rider on the lead and lunge at the beginning of the schooling period. Ridden walk, trot, and canter were introduced stepwise and in the fourth week horses were being exercised five times per week at walk, trot, and canter consecutively (5 minutes each). In the sixth week, horses were exercised on two days only.

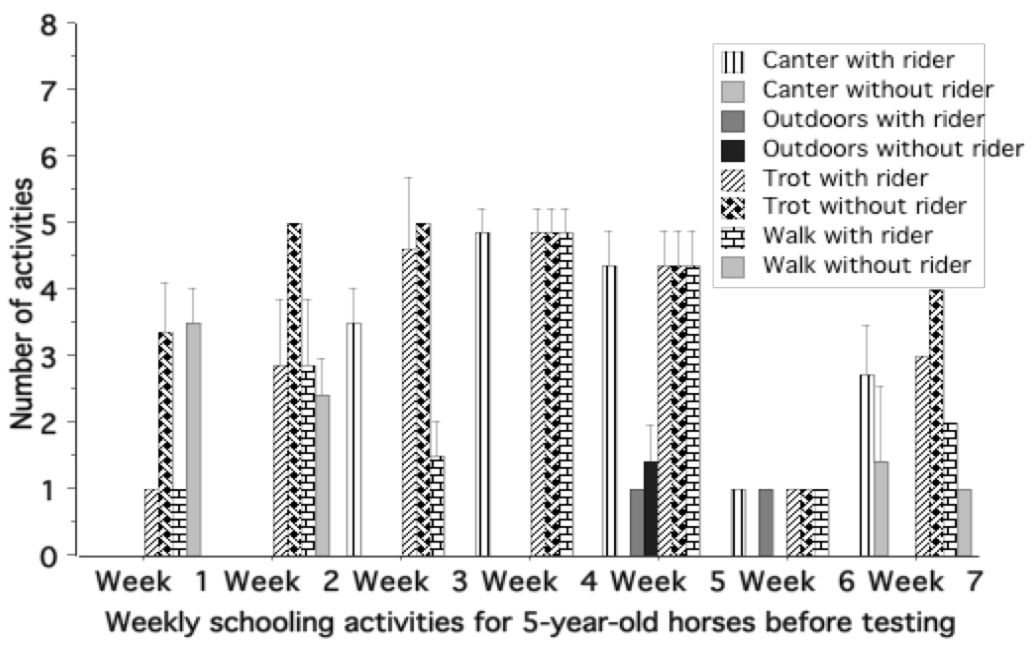

Fig. 1. Number of schooling activities for five-year-old horses naïve to riding, to be prepared for riding during an endurance test ( 8 horses; means \pm standard deviation)

Following the endurance test, horses were not ridden until 10 months later, as sixyear-olds. Then, their endurance was examined twice with seven weeks in between. The first examination was done mid-July, the second one seven weeks after. 
The six-year-olds had a similar preparation for the endurance test mid-July as when five-years-old. Between the two endurance tests they were ridden in weeks 2, 4, 6, and 7 only, as shown in Figure 2. The number of riding days increased over the weeks. During an exercise session, horses walked for five minutes, trotted for ten minutes, and were cantered for another five minutes.

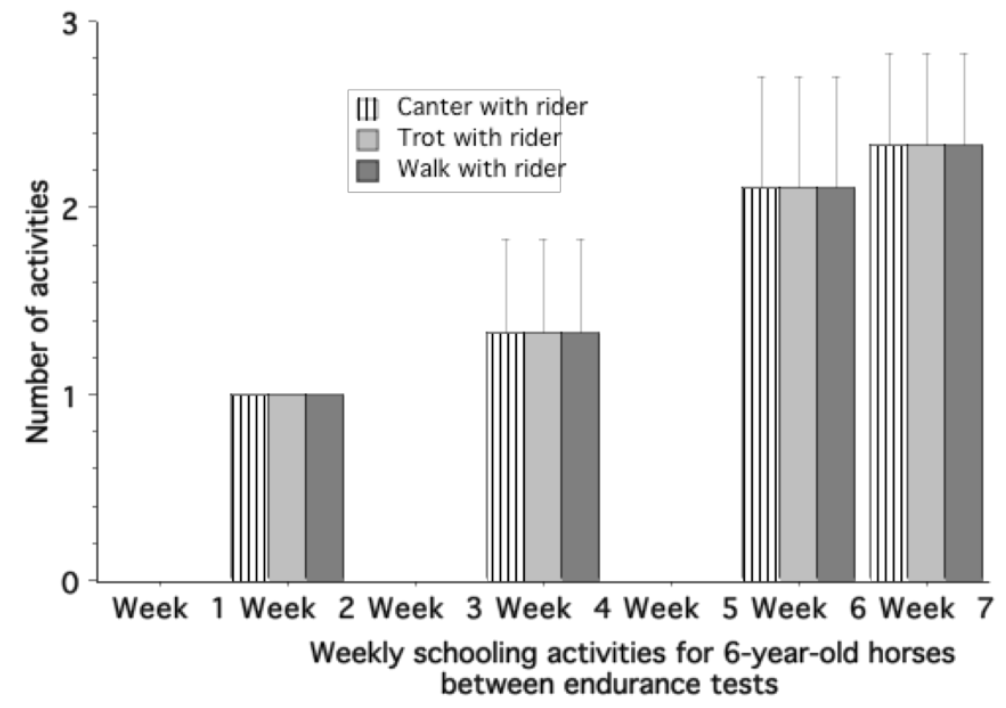

Fig. 2. Number of diverse activities for riding six-year-old horses between endurance tests (9 horses; means \pm standard deviation)

Foreign horses: The owners of a total of 13 horses, not belonging to the stud, accepted the invitation to have their horses tested with the same endurance test and under the same conditions as the five- and six-year-old horses of the stud. The owners were fully aware of the procedures used and interested in the results for the conditioning of their horses. The age, gender, and use of their horses are documented in Table 2.

Table 2

Foreign horses that performed the endurance test

\begin{tabular}{cccc}
\hline Horse & Age years & Gender & Use \\
\hline 1 & 8 & Mare & Eventing \\
2 & 8 & Gelding & Eventing \\
3 & 7 & Mare & Eventing \\
4 & 10 & Gelding & Jumping \\
5 & 8 & Gelding & Eventing \\
6 & 6 & Gelding & Jumping \\
7 & 9 & Gelding & Eventing \\
8 & 6 & Gelding & Horseball \\
9 & 11 & Gelding & Horseball \\
10 & 6 & Gelding & Eventing \\
11 & 4 & Gelding & Eventing \\
12 & 9 & Gelding & School horse \\
13 & 4 & Gelding & Eventing \\
\hline
\end{tabular}

\subsection{Track and endurance test prescription}

The horses were tested on a $130 \mathrm{~m}$ long indoor sandy riding arena. The length of the laps was determined with a distance measuring wheel. The riding path was marked for the riders with red traffic cones. The standardized exercise test (SET) consisted of a maximum of 
five intervals at $3.3 \mathrm{~m} / \mathrm{s}, 4.6 \mathrm{~m} / \mathrm{s}, 5.9 \mathrm{~m} / \mathrm{s}, 7.2 \mathrm{~m} / \mathrm{s}$, and $8.7 \mathrm{~m} / \mathrm{s}$ each. The duration of intervals was between 3-6 minutes. Horses ran a defined number of laps in each interval to reach the prescribed durations (Table 3 ). The increase of speed from interval to interval was such that a continuous increase of the blood lactate concentration (LA) from the concentration before exercise but after warm-up to 4 or more $\mathrm{mmol} / \mathrm{L}$ was obtained in not less than four intervals. This was done to have at least four values to describe the blood lactate-running speed curve and to run the horses as slow as possible to obtain the $4 \mathrm{mmol} / \mathrm{L}$ of blood LA. The SET was discontinued when the blood LA of the horses was at or above $4 \mathrm{mmol} / \mathrm{L}$ (determined on site with Accusport ${ }^{\mathrm{TM}}$; Roche Diagnostics, Mannheim, Germany; [29]. The running speed was determined with a stop-watch by dividing the measured time through the distance run.

Table 3

Standardized exercise test prescription. Length of one lap was 130 meters

\begin{tabular}{cccc}
\hline Interval & $\begin{array}{c}\text { Speed } \\
\mathrm{m} / \mathrm{s}\end{array}$ & $\begin{array}{c}\text { Number } \\
\text { of laps }\end{array}$ & $\begin{array}{c}\text { Total duration } \\
\mathrm{s}\end{array}$ \\
\hline 1 & 3.3 & 9 & 351 \\
2 & 4.6 & 12 & 336 \\
3 & 5.9 & 14 & 308 \\
4 & 7.2 & 17 & 306 \\
5 & 8.7 & 15 & 210 \\
\hline
\end{tabular}

Horses were warmed up for about ten minutes in the arena at all gaits. Horses started and finished an interval always at the same place. Intervals were separated by the time it took to sample blood, in general less than one minute. The direction in which the horses ran the intervals was alternated among intervals. Before the test but after warm-up and within $30 \mathrm{sec}$ after each interval, blood samples were collected for determination of the blood LA by puncture of the jugular vein into Li-heparinized evacuated tubes (Becton Dickinson, Heidelberg, Germany). The v4 was calculated from the blood lactate-running speed relationship by exponential regression analysis with the measured blood LA and a stop-watch determined running speed for each interval of the SET [30].

\section{$2.3 \quad$ Heart rate measurement}

Commercially available heart rate (HR) meters were used for the HR measurements (Polar M400 Equine, Polar Electro GmbH, Buettelbronn, Germany). The HR meters were attached to the thorax of the horses according to the manufacturer's instructions. The HR was recorded at $5 \mathrm{~s}$ intervals. The data recorded by the HR meter were transferred to a computer for analysis with Polar Equine Software (Polar Electro, Finland). The mean HR during each interval was plotted linearly against the speed of the interval and $\mathrm{v}_{180}$ calculated from this relation $\left(\mathrm{v}_{180}=\right.$ velocity run under defined conditions inducing 180 beats $\left./ \mathrm{min}\right)$. The number of $\mathrm{V}_{180}$ values was lower than the number of $\mathrm{V}_{4}$ values because of missing data from the HR meter recordings.

\section{$2.4 \quad$ Data analyses}

All statistics were run on Statview 5.0 (SAS, Cary, NC, USA). The normality of the data was confirmed using the Kolmogorov-Smirnov test. All data are expressed as means \pm standard deviation (SD). Analysis of variance (ANOVA) for repeated measurements was applied to determine whether there were differences among measurements over time. When a significant $\mathrm{F}$ ratio was achieved with the level of significance fixed at $\mathrm{P}<0.05$, post hoc comparisons were accomplished via Fisher's least significant test to locate specific significant differences. The comparison of the means of the endurance variables between five- and six- 
year-olds, between six-year-olds in two consecutive years and between the six-year-olds and foreign horses was accomplished through one-way ANOVA. The significance level was set at $\mathrm{P}<0.05$.

3. Results

3.1 Development of the $\mathrm{v}_{4}$ and $\mathrm{v}_{180}$ of five-year-old horses within one year

The mean values of $\mathrm{v}_{4}$ and $\mathrm{v}_{180}$ of the five-year-old horses at the time of the first endurance test were not significantly different 10 and 12 months thereafter $(\mathrm{P}>0.05)$.

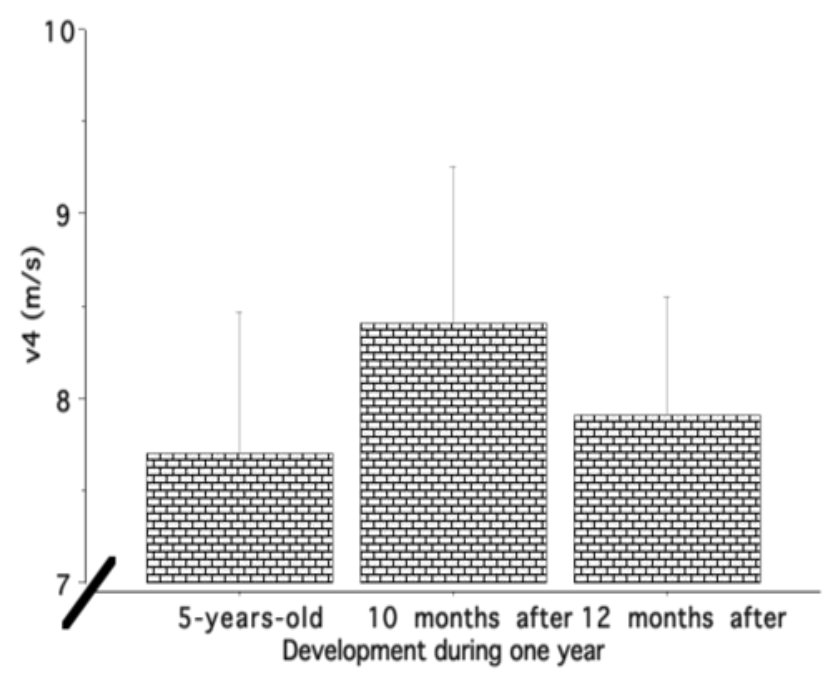

Fig. 3. Development of $\mathrm{V}_{4}$ of five-year-old horses for one year (11 horses; means $\pm \mathrm{SD}$; $\mathrm{P}>$ $0.05)$

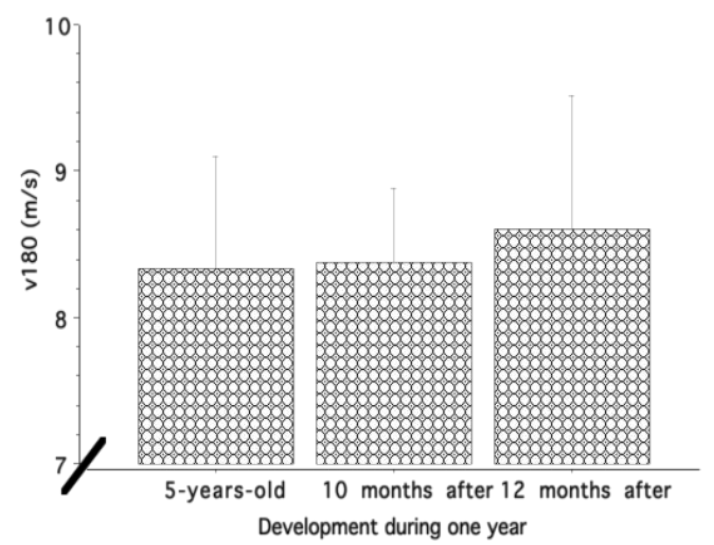

Fig. 4. Development of $\mathrm{v}_{180}$ of five-year-old horses for one year (7 horses; means $\pm \mathrm{SD} ; \mathrm{P}>$ $0.05)$

3.2 Comparison of $\mathrm{v}_{4}$ and $\mathrm{v}_{180}$ between five- and six-year-old horses (means $\pm \mathrm{SD}$ )

The $\mathrm{V}_{4}$ and $\mathrm{V}_{180}$ values were not different between the five- and six-year-old horses (Figures 5 and 6; both $\mathrm{P}>0.05$ ). 


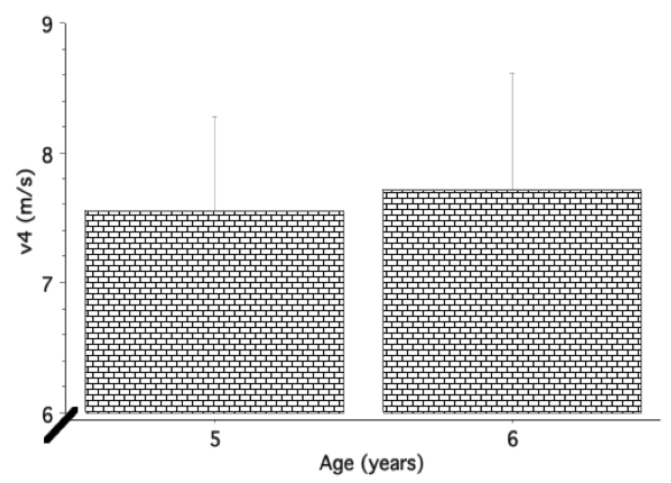

Fig. 5. Comparison of $\mathrm{V}_{4}$ between five- and six-year-old horses (16 and 27 horses respectively; means $\pm \mathrm{SD} ; \mathrm{P}>0.05$ )

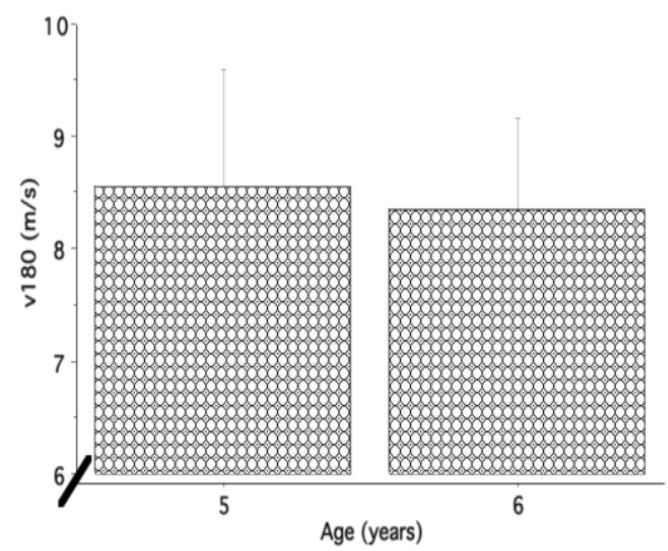

Fig. 6. Comparison of $\mathrm{v}_{180}$ between five- and six-year-old horses (16 and 17 horses respectively; means $\pm \mathrm{SD} ; \mathrm{P}>0.05$ )

\subsection{Comparison of $\mathrm{v}_{4}$ and $\mathrm{v}_{180}$ between six-year-old horses in two consecutive years}

The $\mathrm{v}_{4}$ and $\mathrm{v}_{180}$ values did not differ significantly between six-year-old horse groups measured in consecutive years (Figures 7 and 8 ; both $\mathrm{P}>0.05$ ).

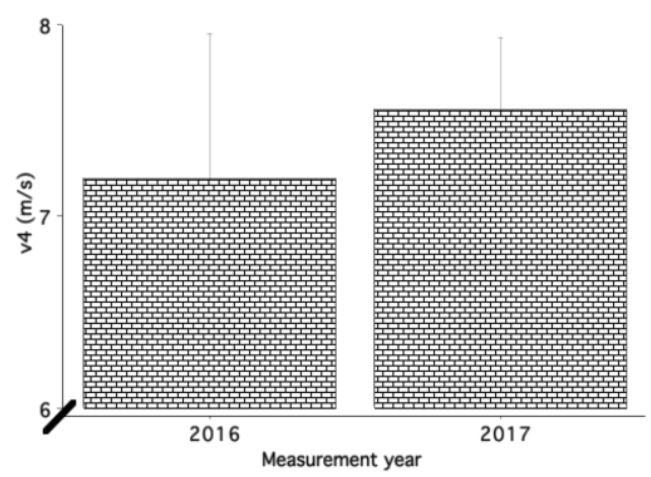

Fig. 7. Comparison of $\mathrm{v}_{4}$ between six-year-old horses in two consecutive years $(10$ and 8 horses in 2016 and 2017, respectively; means \pm SD; P > 0.05) 


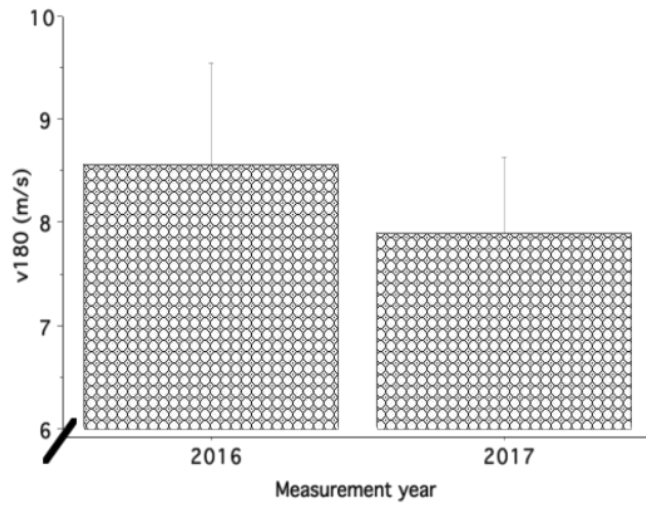

Fig. 8. Comparison of $\mathrm{v}_{180}$ between six-years-old horses in two consecutive years ( 7 and 5 horses in 2016 and 2017, respectively; means \pm SD; P > 005)

\subsection{Relationship between $\mathrm{v}_{4}$ and $\mathrm{v}_{180}$}

The relationship between $\mathrm{v}_{4}$ and $\mathrm{v}_{180}$ of five- and six-year-old horses was not significant (both $\mathrm{P}>0.05$ ). Therefore, all data were pooled, but the relationship remained non-significant (Figure 9; $\mathrm{n}=42 ; \mathrm{P}>0.05 ; \mathrm{r}^{2}=0.02$ ).

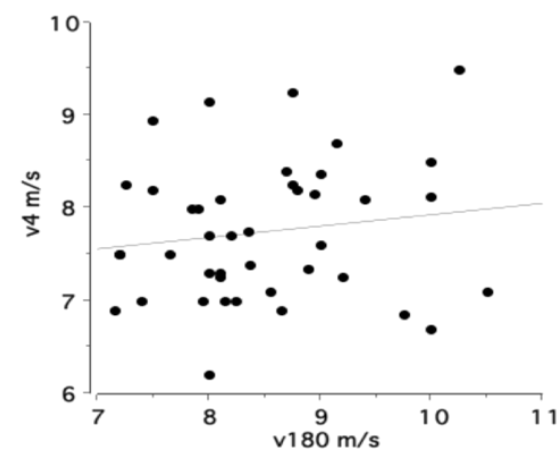

Fig. 9. Relationship between $\mathrm{v}_{4}$ and $\mathrm{v}_{180}$ of five- and six-year-old horses $\left(\mathrm{n}=42 ; \mathrm{P}>0.05 ; \mathrm{r}^{2}\right.$ $=0.02)$

\subsection{Comparison of $\mathrm{v}_{4}$ and $\mathrm{v}_{180}$ between six-year-old and foreign horses}

The tested foreign horses were significantly older than the six-year-old horses of the stud $(\mathrm{P}=0.003 ; 7.39 \pm 2.14$ years $)$. The foreign horses had higher $\mathrm{v}_{4}$ and $\mathrm{v}_{180}$ values than the six-year-old horses $(\mathrm{P}=0.0001$ and $\mathrm{P}=0.003$, respectively; Figures 10 and 11).

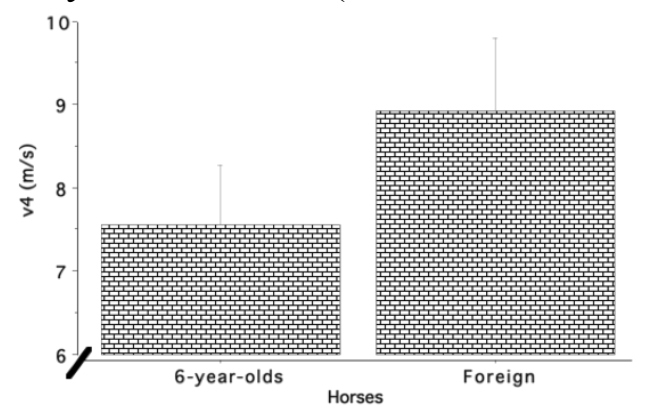

Fig. 10. Comparison of $\mathrm{v}_{4}(\mathrm{~m} / \mathrm{s})$ between six-year-old and foreign horses (24 and 13 horses, respectively; mean $\pm \mathrm{SD} ; \mathrm{P}=0.0001$ ) 


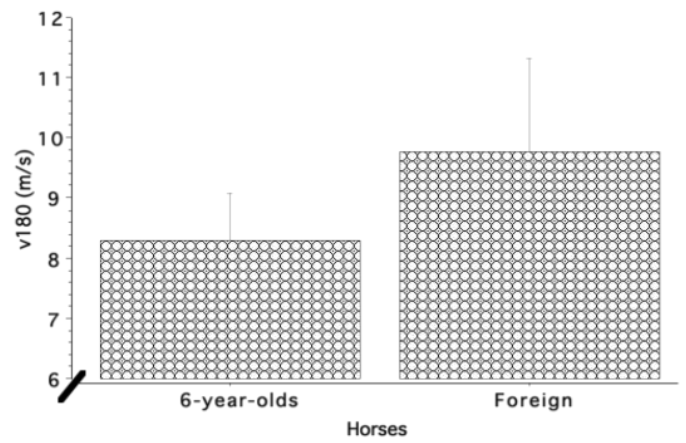

Fig. 11. Comparison of $\mathrm{v}_{180}(\mathrm{~m} / \mathrm{s})$ between six-year-old and foreign horses (17 and 9 horses, respectively; means $\pm \mathrm{SD} ; \mathrm{P}=0.003)$

\section{Discussion}

The stud in which this study was conducted breeds horses for pleasure riding and sports such as show jumping. Their goal is to sell the horses competing with the large majority of breeders who keep horses individually and indoors with reduced social contacts, without the chance to move freely during the whole day and being fed concentrates $[1,2,4-8]$. In contrast, the studied horses are raised in large social groups, kept outdoors year-round on large pastures, and were fed on low-energy food; thus, very close to natural living conditions [1]. Many studies have shown the benefits of such a management system on the health of horses, on their behavior and rehabilitation after intense exercise, ease of handling, and ability to learn tasks $[5,6,9-14,17]$. This is why this project was started to describe the influence of an enriched natural environment on the development of young horses. A preliminary report of the behavior data shows that the socialization of the horses was not finished at the age of four years [31].

Another aspect that differs markedly from the conventional management of horses was that the stud owners allowed their horses to be broken-in and ridden for the first time when they were well into their fifth year of age; thus when, according to literature, their growth is close to or has come to an end already $[18,19]$.

Overall there are not many scientific publications on the effect of management systems on the endurance of horses. Graham-Thiers and Bowen [32] demonstrated that horses kept for 14 weeks on pasture only remained as fit as horses kept stalled during the day and with paddock turnout at night and given additional exercise, while horses kept stalled during the day and with paddock turnout at night only lost fitness. Their results were based on the behavior of plasma LA and HR measurements during a SET. However, their most important finding was that the horses kept on pasture had the highest lateral density of the third metacarpal bone. Horses kept on pasture moved twice as much as the horses in the other groups. The age of the horses was not stated, but most likely they were mature because they were used in a college riding program before being enrolled in the study. The benefit on muscle, bone, tendon, and fitness development of horses kept all day on pasture compared to horses kept in stalls with reduced access or no access to free movement was documented by Rietbroek et al. [33] and Voswinkel [34]. Both studies were conducted with growing horses.

In the present study, the $\mathrm{v}_{4}$ and $\mathrm{v}_{180}$ of the five-year-old horses were not different from those obtained from the same horses 10 and 12 months after the first measurement or of the six-year-olds. This allows the assumption that the endurance of these horses developed to a maximum until the age of five years under the prevailing conditions. The activity data collected for these horses showed that, independent of their ages, the four-, five- and six-yearold horses spent most of their time grazing (with or without walking, $53.0 \% \pm 10.6$ ), then resting $(36.3 \% \pm 9.78)$, and then moving $(4.90 \% \pm 2.24$ excluding grazing while walking). 
This implies that the horses spent a great amount of time moving, especially while foraging or grazing ("active grazing"), exhibiting a long non-intense locomotor activity during a large part of the day [35]. The five-year-olds spent significantly more time resting and less time feeding than the six-year-olds.

Not unexpectedly the foreign horses had higher v4 and v180 values than the six-yearolds. Certainly, age could have affected this result because the mean age of the foreign horses was higher than of the six-year-olds. However, because both horse groups were mature by the time of the endurance tests it is more likely that the higher values of the foreign horses were due to conditioning for their different uses. Another factor that could have influenced the values of the endurance variables was that the six-year-olds were relatively naïve to riding and therefore their moving efficiency might have been lower than that of horses used to being ridden regularly. The gait characteristics of the six-year-olds were measured too and there was no obvious indication that this was the case (Lindner, unpublished). Comparison of the $\mathrm{v}_{4}$ and $\mathrm{V}_{180}$ values determined in this study with those of other studies is not possible because both variables depend on complete standardization [36].

The $\mathrm{V}_{4}$ was selected as the variable to determine the endurance of the horses because it is the variable that is most often shown to be associated with sportive performance of horses [26], including endurance racing [27,37-39], and has been used for some time to examine the effect of conditioning. Increases are considered to show a positive effect of conditioning $[21,22,40,41,42]$. The $\mathrm{v}_{180}$ or $\mathrm{v}_{200}$ have frequently been determined for the same purpose [20], but often without showing a relationship with the sportive performance or endurance of horses as the $\mathrm{v}_{4}$ has done $[24,26,43,44]$ or with the effects of conditioning [23,25]. Evans [45] stated, in his review on the cardiovascular system of horses, that HR during submaximal exercise is an unreliable index of fitness in horses. This may be because of the smaller range of adaptation to conditioning than blood LA and be an explanation for the few publications describing a positive relationship between $\mathrm{v}_{4}$ and $\mathrm{v}_{200}[20,24]$ compared to others supporting the findings of this study $[26,43]$.

\section{Conclusions}

The endurance of the horses raised on pasture in multi-age herds was stable between five- and six-year-olds and did not change within one year in the five-year-olds. It was lower than that of older foreign horses tested under the same conditions. This indicates that keeping horses on pasture all day in multi-age herds alone is insufficient to increase their endurance and that they would benefit from additional exercise to improve it.

\section{Acknowledgment}

We are very grateful to the Fuchs family for providing their horses for the project and accommodation as well as food and good vibes for all those involved in it.

\section{Financial disclosure}

The Verein zur Förderung der Forschung im Pferdesport e.V., Germany funded the project.

\section{References}


[1] Kiley-Worthington M. The behavior of horses in relation to management and training -, towards ethologically sound environments. Eq vet Sci 1990:10:62-71.

[2] Arnemann S. Influence of housing system on the endurance performance of sport horses. Doctoral thesis 2003 University for Veterinary Medicine Hanover, Germany.

[3] Seiler S. Horse Behaviours in the context of well-being, suffering and stress in a freerange system. Bachelor thesis 2014 Technical University Munich, Germany.

[4] Korries O. Untersuchung pferdehaltender Betriebe in Niedersachsen Bewertung unter dem Aspekt der Tiergerechtheit, bei Trennung in verschiedene Nutzungsgruppen und Beachtung haltungsbedingter Schäden. Doctoral thesis 2003 Veterinary Medicine University Hanover, Germany

[5] Petersen S, Tölle KH, Blobel K, Grabner A, Krieter J. Erhebungen zur Pferdehaltung in Pensionsbetrieben in Schleswig-Holstein. Züchtungskde 2006;78:207-17

[6] Hartmann E, Søndergaard E, Keeling LJ. Keeping horses in groups: a review. Appl Anim Behav Sci 2012;36:77-87.

[7] Hartmann E, Bøe KE, Christensen JW, Hyyppa S, Jansson H, Jørgensen GHM, et al. A Nordic survey of management practices and owners' attitudes towards keeping horses in groups. J Anim Sci 2015;93:4564-74.

[8] Ruet A, Lemarchand J, Parias C, Mach N, Moisan MP, Foury A, Briant C, Lansade L. Housing Horses in Individual Boxes Is a Challenge with Regard to Welfare. Animals 2019;9:621.

[9] Connysson M, Rhodin M, Jansson A. Effects of Horse Housing System on Energy Balance during Post-Exercise Recovery. Animals 2019;9:976. doi:10.3390/ani9110976.

[10] Waters AJ, Nicol CJ, French NP. Factors influencing the development of stereotypic and redirected behaviours in young horses: findings of a four year prospective epidemiological study. Eq vet J 2002;34:572-79.

[11] Nover M. Status quo der Haltung von Pferden in einer Region Westdeutschlands unter Aspekten des Tierwohlbefindens. Doctoral thesis 2013 Free University Berlin, Germany.

[12] Thelen A. Zusammenhang zwischen Haltungsformen, Verhaltensstörungen und Erkrankungen bei Pferden unterschiedlicher Verwendungsrichtung. Doctoral thesis 2014 University of Gießen, Germany.

[13] Yngvesson J, Torres JCR, Lindholm J, Pättiniemi A, Andersson P, Sassner H. Health and Body Conditions of Riding School Horses Housed in Groups or Kept in Conventional TieStall/Box Housing. Animals 2019;9:73; doi:10.3390/ani9030073

[14] Rivera E, Benjamin S, Nielsen B, Shelle J, Zanella AJ. Behavioral and physiological responses of horses to initial training: the comparison between pastured versus stalled horses. Appl Anim Behav Sci 2002;78:235-52.

[15] Søndergaard E, Ladewig J. Group housing exerts a positive effect on the behaviour of young horses during training. Appl Anim Behav Sci 2004;87:105-8. 
[16] Wille ML. Single versus group housing- the effect of two different housing conditions on the welfare of horses. Doctoral thesis 2011 University Munich, Germany.

[17] Keeling LJ, Bøe KE, Christensen JW, Hyyppa S, Jansson H, Jørgensen GHM, et al. Injury incidence, reactivity and ease of handling of horses kept in groups: A matched case control study in four Nordic countries. Appl Anim Beh Sci 2016;185:59-65.

[18] Zietschmann O, Krölling O. Lehrbuch der Entwicklungsgeschichte der Haustiere, 2. Auflage, Parey Verlag Berlin und Hamburg, Germany; 1955.

[19] El Salam Ragab Mahasen Abd (1976): Die röntgenologische Darstellung der Epiphysenfugen der Halswirbel beim Pferd und die Bestimmung ihrer Schließungszeiten. Doctoral thesis 1976 Veterinary Medicine University Hanover, Germany.

[20] Persson SGB. Evaluation of exercise tolerance and fitness in the performance horse. In: Snow DH, Persson SGB, Rose RJ, editors. Equine Exercise Physiology 1. Granta Editions, Cambridge, UK; 1983, p. 441-57.

[21] Auvinet B, Galloux P, Michaux JM, Franqueville M, Lepage O, Ansaloni-Galloux A, Coureau C. Test d' effort standardisé de terrain pour cheveaux de concours complet (TEST). Science Sports 1991;6:145-52.

[22] Straub R, Isler R, Gysin J. Parameter zur Beurteilung der Ausdauer des Pferdes. Tierärztl Praxis 1984;12:499-504.

[23] Sloet van Oldruitenborgh-Oosterbaan M. Heart rate and blood lactate in exercising horses. PhD thesis 1990 University Utrecht, the Netherlands.

[24] Couroucé A. Epreuve d'effort standardise de terrain apliquee au cheval trotteur. PhD Diss. 1997 University of Jean Monnet Saint Etienne, France.

[25] Trilk JL, Lindner A, Greene HM, Alberghina D, Wickler SJ. A lactate-guided conditioning program to improve endurance performance. Eq Vet J Suppl 2002;34:122-5.

[26] Lindner A. Relationships between racing times of Standardbreds and v4 and v200. J Anim Sci 2010 a;88:50-4.

[27] Fraipont, A, Van Erck E, Ramery E, Fortier G, Lekeux P, Art T. Assessing fitness in endurance horses. Can Vet J 2012;53:311-4.

[28] Munk R, Møller S, Lindner A. Effects of training with different interval exercises on horses used for show jumping. Comp Exerc Physiol 2013;9:33-41.

[29] Lindner A. Measurement of plasma lactate concentration with Accusport ${ }^{\circledR}$. Eq Vet J 1996;28:403-5.

[30] Galloux P. Contribution à l'élaboration d'une planification de la study; préparation énergétique du cheval de concours complet suivi de l'entraînement par la mesure de la fréquence cardiaque et le dosage de la lactatémie. PhD thesis 1991 University of Poitiers, France. 
[31] Valenchon M, Lindner A, Hennes N, Gérard C, Petit O. Une maturation sociale et comportementale tardive? Proceedings 2019 Journées Sciences \& Innovations Équines. Saumur, France; Video at https://www.youtube.com/watch?v=iUVmWXamNM\&list=PLATYrVnX3WHW rtdvG7yi4ZtkirbYF7Ie\&index $=12 \& \mathrm{t}=0 \mathrm{~s}$

[32] Graham-Thiers PM, Bowen LK. Improved Ability to Maintain Fitness in Horses During Large Pasture Turnout. J Eq Vet Sci 2013;33:581-5.

[33] Rietbroek NJ, Dingboom EG, Schuurman SO, Hengevard-vander Wiel E, Eizema K, Everts ME. Effect of exercise on development of capillary supply and oxidative capacity in skeletal muscle of horses. Am J Vet Res 2007;68:1226-31.

[34] Voswinkel L. Einfluss der Bewegungsaktivität auf Wachstums- und Ausdauerparameter beim Pferd. Doctoral thesis 2009 University Kiel, Germany.

[35] Valenchon M, Petit O. Effect of an enriched social environment on development, welfare and physical performances of horses". Report 2018 for Verein zur Foerderung der Forschung im Pferdesport e.V., Juelich, Germany.

[36] Köster A. Reproduzierbarkeit von in Belastungstests ermittelten Leistungskennwerten (v2, v3, v4, v12, und v150, v180, v200) und deren Beeinflussbarkeit durch die Stufendauer bzw. Streckenlänge bei Pferden auf dem Laufband. Doctoral thesis 1996 University of Gießen, Germany.

[37] Demonceau T. 1989 Appreciation de l'Aptitude Physique du Cheval d'Endurance: Interet du Seuil Anaerobie Lactique. Ph.D. Thesis 1989 Ecole Nationale Veterinarie d'Alfort, Maisons-Alfort, France.

[38] Erickson HH, Erikson BK, Lundin CS, Gillespie JR, Coffman JR. Performance indices for the evaluation of the equine athlete. Proc Am Assoc Equine Pract 1990;36:457-69.

[39] Lindner A. Applied sport science for horses trained in Germany for endurance racing. Pferdeheilkde 2010 b;6:255-63.

[40] Thornton JR, Essén-Gustavsson B, Lindholm A, McMiken D, Persson SGB. Effects of training and detraining on oxygen uptake, cardiac output, blood gas tensions, $\mathrm{pH}$ and lactate concentrations during and after exercise in the horse. In: Snow DH, Persson SGB, Rose RJ, editors. Equine Exercise Physiology 1. Granta Editions, Cambridge, UK; 1983, p. 470-86.

[41] Von Wittke P, Lindner A, Deegen E, Sommer H. Effects of training on blood lactaterunning speed relationship in thoroughbred racehorses. J Appl Physiol 1994;77:298-302.

[42] Wilson RG, Isler RB, Thornton JR. Heart rate, lactic acid production and speed during a standardized exercise test in Standardbred horses. In: Snow DH, Persson SGB, Rose RJ, editors. Equine Exercise Physiology 1. Granta Editions, Cambridge, UK; 1983, p. 487-96.

[43] Ponchard MT. Equine exercise prescription and talent identification based on plasma lactate kinetics. PhD thesis 1998 University Western Australia, Perth, Australia. 
[44] Leleu C, Cotrel C, Barrey E. Predictive interest of physiological and gait variables in French trotters. In: Lindner A, editor. The Elite Race and Endurance Horse. CESMAS, Arbeitsgruppe Pferd, Germany; 2004, p. 89-93.

[45] Evans DL. 1994. The cardiovascular system: Anatomy, physiology and adaptations to exercise and training. In: Hodgson DR, Rose RJ, editors. The Athletic Horse. WB Saunders Company, Philadelphia, PA, USA; 1994, p. 129-44. 


\section{Animal welfare statement}

The horses involved in this study were continuously monitored by equine veterinarians and the owner consented to all procedures and disclosure of the findings.

The owners of a total of 13 horses, not belonging to the stud, accepted the invitation to have their horses tested with the same endurance test and under the same conditions as the fiveand six-year-old horses of the stud. The owners were fully aware of the procedures used and interested in the results for the conditioning of their horses. 